\title{
クモ膜囊胞の発生ならびに成長因子に関する検討
}

\author{
手術症例および剖検例の検索による \\ 中川 義信·西田 憲記·松本 圭蔵·Jorge Cervós-Navarro*·Juan Jose Artigas* \\ Jose Iglesias*
}

\section{Etiology of Arachnoid Cysts}

\author{
Review of Surgical and Postmortem Findings \\ Yoshinobu Nakagawa, Kenki Nishida, Keizo Matsumoto, \\ Jorge Cervós-Navarro*, Juan Jose ARTigas* and Jose Iglesias* \\ Department of Neurosurgery, the University of Tokushima, Tokushima; ${ }^{*}$ Neuropathologische Institut der \\ Freie Universität, Berlin, B.R.D.
}

\begin{abstract}
Postoperative reduction in the size of arachnoid cysts was examined in 48 surgical cases. In these and 11 autopsy cases, the cyst walls were examined histologically. Nine cases showed less than $20 \%$ reduction, 27 exhibited reduction of 30 to $80 \%$, and 12 showed over $90 \%$ reduction in cyst volume. The outer walls of every cyst were found to contain arachnoid membrane. Interestingly, the walls of two cysts contained choroid plexus. One of these, initially detected by computed tomography, was in the middle cranial fossa. Because of its transparent, glistening membrane, observed at operation, it was considered to be an arachnoid cyst. Recurrence of symptoms and cyst formation rendered reoperation necessary. In the outer membrane of the wall of the cyst removed at the second operation, choroid plexus-like tissue was observed microscopically. In the second case, a small cyst resembling an arachnoid cyst was incidentally found at autopsy in the cerebellopontine angle. A small tuft containing choroid plexus was present on the floor of the cyst. Both cases were diagnosed as arachnoid cysts on the basis of histological examination of specimens of their outer membranes. The authors postulate that heterotopic choroid plexus in the subarachnoid space can secrete cerebrospinal fluid (CSF) and may split the arachnoid membrane, thus forming a growing cyst. In another interesting case, after craniotomy and total removal of a malignant choroid plexus papilloma, a large cyst resembling an arachnoid cyst appeared in the left frontal lobe along the tract of the ventricular drainage. The cyst seemed to have formed from CSF secretion from the metastatic choroid plexus. This case appears to support the authors' hypothesis.
\end{abstract}

Key words: arachnoid cyst, ependymal cyst, choroid plexus papilloma, cerebrospinal fluid

\footnotetext{
徳島大学脳神経外科 *ベルリン自由大学神経病理研究所

Address reprint requests to: Y. Nakagawa, M.D., Department of Neurosurgery, National Kagawa Children's Hospital, 2,603 Zentsuji-cho, Zentsuji, Kagawa 765.

受稿 1986年6月26日受理 1988年4月18日
} 


\section{I はじめに}

ク王膜售胞の成因については，Starkman ら ${ }^{14) ゃ ~}$ Robinson ${ }^{11)}$ により詳細な病理学的な検索が行われている が，発生要因についてはいまだ議論の多いところである。

一方，脳神経外科の分野では，こ引いった襄胞を有する患 者に対してさまざ季術方法が試みられている。すなわ ๖，開頭による衰胞壁切除術，䨢胞一腹腔短絡術扎よびこ れらを組み合せた万法などである。ところが，クモ膜蒹胞 と診断された患者に対し，こういった手術法を試みても， いつも良好な結果が得ら机るとは限らないのが現状であ る、このよ5な患者に対する治療の必要性の有無を判断し たり，いかなる手術方法が有效か否かを論ずる際には，輁 胞の発生要因のみでなく，笙胞が扗大してくる機構をも解 明する必要があると思われる。現在のところ, 衰胞が成 長・拡大してくる成因として考えられているのは，(1) ball-valve 現象もしくは(2)浸透圧の差に基づく襄胞腔の拡 張, (3)動脈もしくは静脈圧の変化によるVirchow-Robin 腔を通じた䯣液の移行などとされている16)。さらに，臨床 的にみた場合，これらの䧶胞を有する患者のなかには脳圧 六進症状を呈したり局所症状を呈するものが存在する一 万，まったく占挑性物質としての性格を示さないものも存

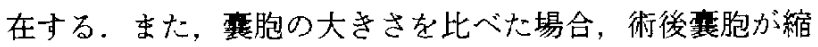
小するものからまったく小さくならないるのや，いったん 縮小したるのが再び大さくなるものなど，必ずしも同じ傾 向を示すとは限らない，当然のことながらこれらの手術 結果の違いは手術方法に起因していることも考觉られる が，必ずしもそれがすべてとも思加なない

そこで，今回我々はクモ膜襄胞を有寸る患者のなかには 他の原因による，これをで知られていない襄胞腔払大をも たらす因子を有なる症例存在するのではないかと推定 し，追跡可能であった手術症例 48例の襄胞腔の縮小率を検 討するととるに，剖検により得られた11例の標本を加え， 計59例の組織学的な検索を再度詳細に行った。友の結果, 2 例においてクモ膜栾胞壁內に choroid plexus 様の構造物 が認められた。そこで，これら2症例を報告するととる に，経過中に arachnoid cyst 様の囊胞が発生した malignant choroid plexus papilloma 1 症例を併せて報告し，

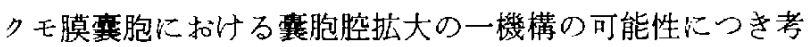
察を加えた。

\section{II 対象および方法}

\section{1.クモ膜趸胞の術後における縮小率について}

CT 導入以来, ク王膜襄胞との診断で手術が行われ，そ の後 2 年以上の follow-up が行水れた 48 症例について, 輁
胞の穛小率を CT 所見より求めた。なお， クモ膜囊胞に対 する手衍法は，原則として開頭および襄胞壁部分切除術で ある、襄胞壁の切除は原則として外壁に対してのみ行って いるが，中頭蓋裔に発生した輁胞に対しては，内壁の一部 b切除し， basal cistern への交通か十分につくよ5にして いる。蒦胞腔の縮小のみられなかった一部の症例では，一 定期間を括いて，さらに輁胞一腹腔短絡術を施行してい 万.

䧶胞壁の縮小率については，すでに一度報告されてい $ろ^{81} か^{*}$, orbito-meatal line に平行に slice 幅 $10 \mathrm{~mm}$ として 撮影された像で，整胞がもっとる大きく描出された slice を用いて比較検討が行われた。

\section{2. 組蟣学的検討}

対象となったのは，手術の行われた48症例に加之，剖検 によりクモ膜裹胞が明らかとなった11症例を合せた計59症 例である。検索には HE， Mallory，PTAH， Elastica van Gieson染色などを用いた。さらに，一部の症例では電蹎 的検索我行った。

\section{III 結 果}

\section{1.クモ膜焉胞の術後における縮小率について}

術後90〜100\%の襄胞の樎小をみたものは12例(25\%)で あった，術後粪胞の縮小傾向は認めら㧈たものの，必ずし も十分ではなく，30〜80\%の縮小率と判定されたたのは27 例 $(56 \%)$ ，さらに汪とんど表胞の縮小が認められず，縮小 率が0〜20\%と判断された症例は9例(19\%)であった (Fig. 1).

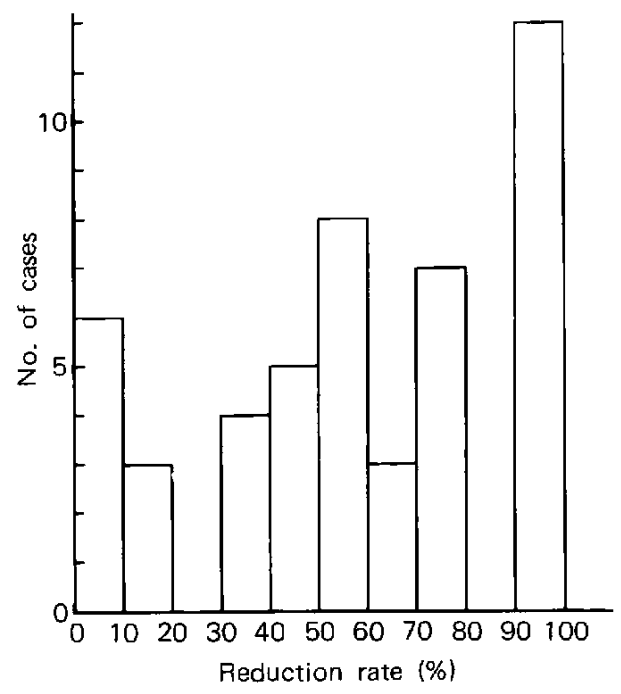

Fig. 1 Postoperative reduction in size of arachnoid cysts as demonstrated by computed tomography (CT) ${ }^{8}$ ) 

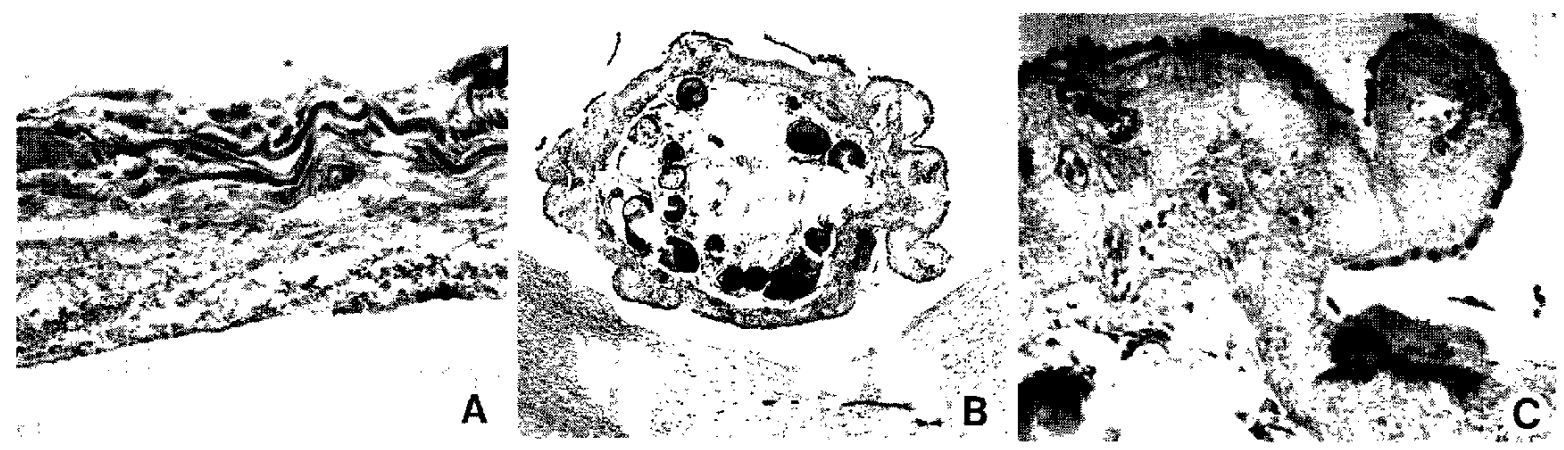

Fig. 2 Case 1. A: The thin cyst wall is composed of arachnoid cells surrounded by a band of glial tissue. HE stain, $\times 400$. B: In the floor of the cyst there is a tuft composed of a pedicle, vascularized fibrous tissue, and psammoma bodies. HE stain, $\times 100$. C: Higher magnification showing non-ciliated cuboidal epithelium. HE stain, $\times 400$.

\section{2. 組䋘学的検討}

検討を行った全症例に括いて，要胞壁全体もしくは一部 にクモ膜細胞より成る模様成分が認められ，組織学的には 全例クモ膜襄胞との診断が下された。また，検索しえたか ぎりでは，薯胞の外膜ならびに腷表面に密着した内膜のい ずれに颃いてもクモ膜成分が認められており,これらの襄 胞はいわゆる intra-arachnoid cyst の範疇に入るものと推 定された。しかしながらこのらち2例において，豪胞内 もしくは檋胞壁内に choroid plexus 様の組轼が認められ た。

そこで，以下，これら2 症例を報告するとともに，経過 中クモ膜整胞の発生をみた malignant choroid plexus papillomaの 1 例を併せて報告する．

\section{$N$ 症例}

<症例 $1>75$ 才，女性

大腸癌により死亡．死亡以前にはなんら神経学的な異常 法認められていない，剖検時，右小脳橋角部に $3 \times 4 \mathrm{~cm}$ の襄胞が偶然発見された(Fig. 2A). 肉眼的には慗胞壁は 光沢を有した半透明膜によりできており，この膜は肥厚し

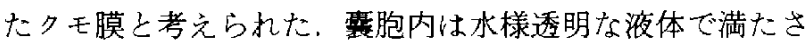
れており，䨢胞による小脳橋角部に対する著明な圧迫所見

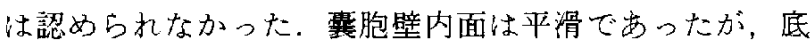
部，すなわち豊胞と小脳が接する部位に霊胞内に突出した 小さな $(2 \times 5 \mathrm{~mm})$ 隆起が認められた(Fig. 2B)。

組織学的所見：襄胞壁は比較的厚い結合組織上り成って 㧍り，その外側には一部グリア細胞が認められた。䧶胞壁 内面はクモ膜細胞により構成され，組織学的にクモ膜囊胞 と考之られた，ところが，衰胞内に突出した部位を挨索し たところ，隆起物の付着部は一層の偏平な細胞に移行し， その直下はグリフ層であった。この隆起物は psammoma bodyを有し，立方上皮細胞より成る choroid plexus と思 われる組織像を呈していた(Fig. 2C).

<症例 2>71才, 女性

ジャクンン型の痤攣発作を主訴に入院，CTにて右側 頭・頭頂部に低吸収域を呈する襄胞が認められた。神経学 的には左顔面知覚障害か認められ，頭蓋内压方進症状に上 る頭痛を訴えていた。CT所見よりクモ膜霓胞が疑われ， 開頭・震胞壁切除術が施行された。術中所見としては囊胞 は透明な膜により覆われており，㷮胞内は水様透明な液で 満たされ，いわゆるクモ膜襄胞と考兄られた。そこで，䧶 胞外壁広範囲に切除したのち，手術を終点た，術後経過 は良好で，霊胞注縮小しておう，症状の軽快もみられてい た。しかしながら, 2 力月後, 再びジャクンン痤擎が出

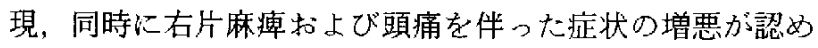
られた。CTを再検したところ, 異胞の再膨張がみられた ため，再び開頭術を施行，異胞壁を部分切除したのち，噀 胞一腹腔短絡術を施行した，術後経過は順調であり，CT 上襄胞の縮小を認め, 臨床的にも症状の著明な改善をみて いる.

組綫学的所見：襄胞壁は collagenに囲まれたクモ膜細胞 上り成り立っていた，一部には線維芽細胞の增生がみられ たが，炎症所見は認められなかった，興味あることには， これらの組織内に混じり，小さな choroid plexus 様の組織 像が認められた(Fig. 3A)。そこで, 同一部位を電顕学的 飞検索したところ，これらの組織は一層の立方上皮細胞上 り成り, microvilli が認められた(Fig. 3B，C)。これらの細 胞間腺には zonula adherens および zonula occludens が認 められた。またこれらの細胞には基底膜が存在してい た，以上より，こ机らの組織は choroid plexus と考克られ た. 


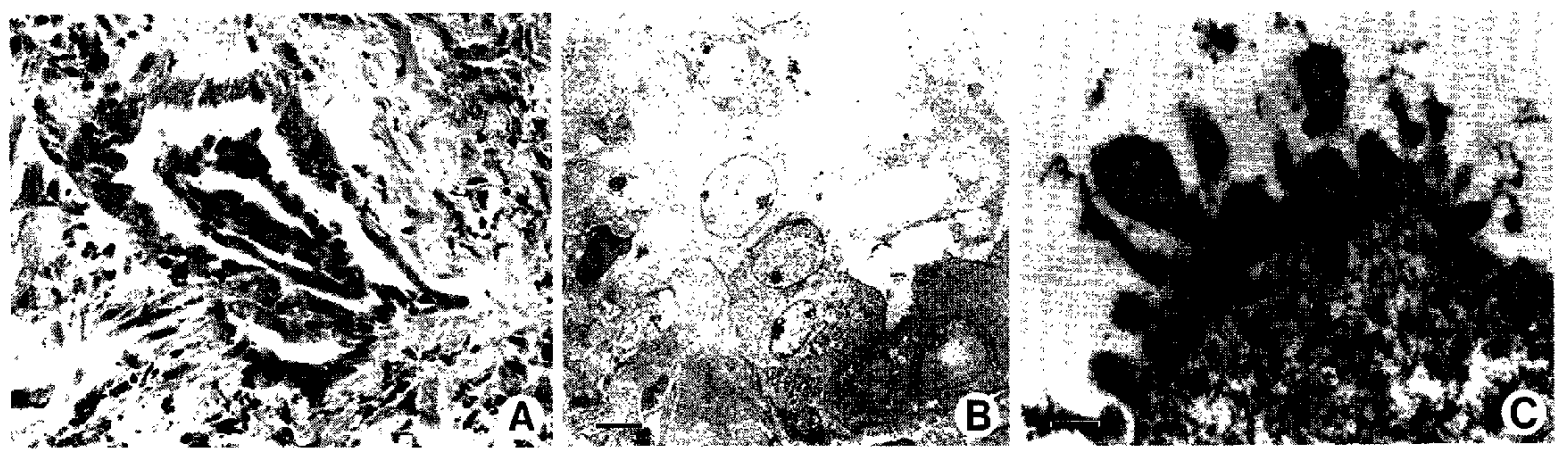

Fig. 3 Case 2. A: Section of a choroid plexus-like structure composed of columnar epithelium with proliferating fibroblasts and no inflammatory infiltration. Goldner stain, $\times 400$. B: Electron microphotograph showing a papillary structure composed of a monolayer of cuboidal cells. Bar $=10 \mu \mathrm{m}$. C: Higher magnification showing sparse, widely spaced microvilli of irregular length. Bar $=0.25 \mu \mathrm{m}$.
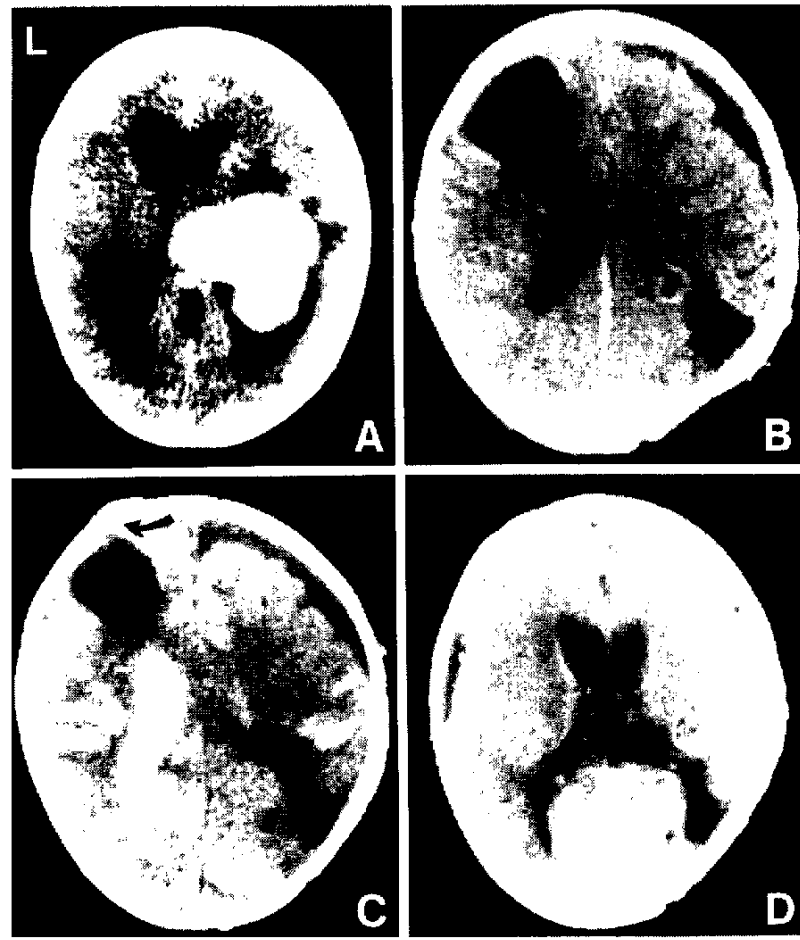

Fig. 4 Case 3. A: Preoperative CT scan showing an enhanced tumor in the right lateral ventricle. B: Three months after surgery, a cystic lesion was demonstrated in the left frontal lobe. C: Metrizamide CT scan. There is no communication between the ventricular system and the cyst. The ventricular drainage tract is also demonstrated (arrow). D: Follow-up CT after the second operation. The cystic lesion in the left lateral lobe and the tumor in the right lateral ventricle are not detected.
<症例 $3>1$ 才, 男児

頭蓋内王え進症状にて発症，CT およひ脳血管撮影所見 より右側脳室内に発生した腫煌と診断された(Fig. 4A). 脳室抎大が著明なため, 左側脳室ドレナージを行ったの ち，開頭・腫瘍摘出術が行われた，術後経過は良好で方っ たが, 術後 3 力月目頃より左側側頭葉内に脳室ドレナージ の穿刺路に沿って霊胞形成がみられた (Fig. 4B，C).そこ で，開頭および囊胞壁切除術を施行したところ，䨢胞は透 明なクモ膜により覆わ机ていた。これを十分に切除したの ら，衰胞腔と側脳室前角を開き，両者の間に交通を十分に つけた。術後，襄胞は縮小し，症状の改善をみた(Fig. 4D). その後, 組織学的に malignant choroid plexus papilloma と診断さ机たため, 放射線療法と化学療法を追加施 行した。しかしながら，6力月後，脊䯣転移をきたし，死 亡した。

組織学的所見：摘出した腫瘍は乳頭状構造を形成してい るが，細胞の重層化，クロマチンに富み，核の大小不揃い がみられ，mitosis 死多くみられた。 PAS 染色は陰性であ った，以上より，anaplastic choroid plexus papilloma と診 断された。また，左前頭部襄胞壁はクモ膜により形成され て㧍り、この襄胞に限っての及言及すれば， arachnoid cyst の範疇に入るむのと考党られた。

\section{$\mathrm{V}$ 考察}

CTが脳神経外科領域に導入されて以来，頭蓋内に董胞 性病変，ことにクモ膜䤑胞を有する患者の診断は容易之な り，患者の数名急增している、こういった患者は襄胞の珐 迫による頭蓋内珐元進症状，すなわち頭痛，湢吐といった 症状を呈したり，全身痓㝈，片麻痺といった局所症状を主 訴とするものが多(8)、しかし，なかには頭蓋内生え進に 
よらない頭痛や交通事故後などの精查中にこらいった霆胞 が偶然発見されることも少なくない，生たこういった患 者に対し，年の手術適応子含め，い加なる手術法を選択寸 るかといったことに関しては，いまだ議論が多くなされて いるところである。春際には開頭を行い，檋胞壁を除去す る方法，さらに近接するクモ膜下腔との交通を十分につけ る方法，あるいは襄胞一腹腔短絡術，もしくはこれらの組 み合せなどが行われている。しかし，これらの手術法のい ずれを選択しても必ずしもいつも良好な結果を得られると は限らず，これら囊胞が完全に消失する割合は30〜70\%と 言われている7! 。た，開頭・囊胞壁切除術後に裏胞の縮 小がみられなかった場合，囊胞一腹腔短絡術を行ったとこ ろ，䨢胞が縮小したとの報告も散見される ${ }^{5)}$. 今回報告し た我々の 1 例も同様の経過をとっている，ところで，こう いった差は一体なぜ生じてくるのであろらか。

クモ膜輁胞の成因に関する組織学的な検討は古くから行 われ，数多くの報告がみられる，最初の報告は1831年， Bright $^{2)}$ により行われ，裹胞はクモ膜間(intra-arachnoid)に 存在していたる記載されている，その後，Robinson ${ }^{11} の$ agenesis theory 初めとして, 先天奇形説など色々な説が みられるが，Bright の報告から127年後，Starkman $5^{14) か ゙ ~}$ 再びBright と同様の病理学的所見を詳細に報告した。以 後，クモ膜裹胞がクモ膜の間汇発生したとする，いわゆる intra-arachnoid cyst であるといった説は多くの報告者によ り支持されることとなった10,15)。ところが，こういった豪 胞がクモ膜間隙内にいかにして形成されるのか，またいか にして膨張し，占掬性病变となるのかといった点に関して は，いまだ納得の行く論証はない，現在のところ，可能性 として挙げられているのは, (1) secretion of fluid by ependymal cells, (2) fluid ingress due to an osmotic gradient, (3) trapping of fluid by ball-valve mechanism, (4) an aberration in the flow of cerebrospinal fluid in the endomeninx なとであ $ろ^{5)}$.

このうち, (1)の ependymal cell からの髄液の分泌関し ては，もっともありらることと考充られるが，病理学的に 襄胞壁に ependymal cell lining が認められた場合には ependymal cyst と診断されており，これは arachnoid cystとは 明確に区別されている12)，末た，(2)の浸透匤の差や(3)の ball-valve mechanism に関しては, isotope やmetrizamide が髄腔内へ注入されたのち，3〜6時間を経てゆっくりと 震胞内へ流れ込む症例が存在することより，もっとも可能

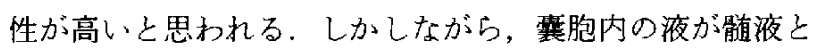
まったく同じ成分であったとの報告がみられることや，術 後輁胞が縮小しない例が存在することを考え合せるとここ らいった機構ですべてのクモ膜囊胞の成因を説明しきれる
ものでもない.ささらに，(4)の venous pressure むしくは arterial pressure の影響で血管周团のクモ膜間隙を髄液が クモ膜内への一方向へのみ流れ込み，同様の囊胞を形成与 るといった説もあるが， metrizamide CTで metrizamide が注入直後より多量に裏胞内人流入したり，時間経過とと もと流出する症例が存在したことなどを考光合せると，こ の説も ball-valve mechanism 同様，必ずしもすべての襄胞 形成を説明できるものではない。

今回我々の経験した症例は，っモ膜囊胞を形成した壁内 に choroid plexus が存在し，それによる髄液の産生が䧶胞 腔の形成・拡大の因子となったものと考息られた例であ る.こういらた笨胞に対し, 病理学的に arachnoid cyst $と$ 診断することが正しいか否かは別として, ependymal cell lining と異なり，arachnoid cellにより形成されたクモ膜整 胞の壁の一部にこらいった choroid plexus が混じている場 合には，肉眼的にはもらろん，光顕的にみても発見されが たく，それ故見逃されている可能性が十分に考えられる。 我々脳神経外科医が上く経験する上うに，開頭・亳胞壁切 除術を絽り返し行っても襄胞の縮小がみられなかったり， 再搪張が生じてくるような症例のなかには、このよらな choroid plexus の存在する可能性も一部には存在するので はないかと推測される。こう考えてみると，クモ膜豪胞は 組織学的にはクモ膜内に形成された襄胞であるといった点 は一致するものの，その形成過程には色々な可能性が存在 していると思和れる。また，臨床的にも頭蓋内圧六進症状 をきたするのから局所症状を呈するるのや無症状のものま で存在している。こういった点より，CT上囊胞として描 出され，肉眼的には透明な膜で覆われた震胞で，さらにこ れらの膜が光顕的にクモ膜細胞から成り立っているよらな 症例を全例》モ膜襄胞と診断し，画一的に処理するには問 題があるように思われる. 最近, 志村ら ${ }^{13)}$ にり，一見ク モ膜襄胞類似の衰胞の壁を電顕的に詳練に検索した結果， neuroectodermal cystであったとの報告もなされており，

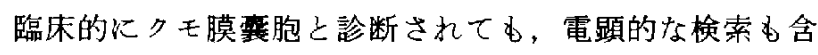
め,も5一度詳細な組織学的検討が必要なのではないかと 考えられた。

実際に我々の経験した症例と類似の症例と考えられた報 告は，1955年，Kahm 5 5)，1956年，Handa and Bucy ${ }^{4)}$ 亿 よってなされて和り，以後に必散見される゙。このよらな 症例は必ずしもまれなものではなく，今後クモ膜囊胞を报 う場合，十分な注意と興味を持って検索する必要があると 思わ机る。また，我々がこの推測を行った根拠の一つとし て，1951年，Cooper ら ${ }^{3)}$ が正常例に打りるクモ膜下腔を 検索したところ，正常と思われたクモ膜下腔に heterotopic glial nests が存在したことを報告して招り，しかもこのう 


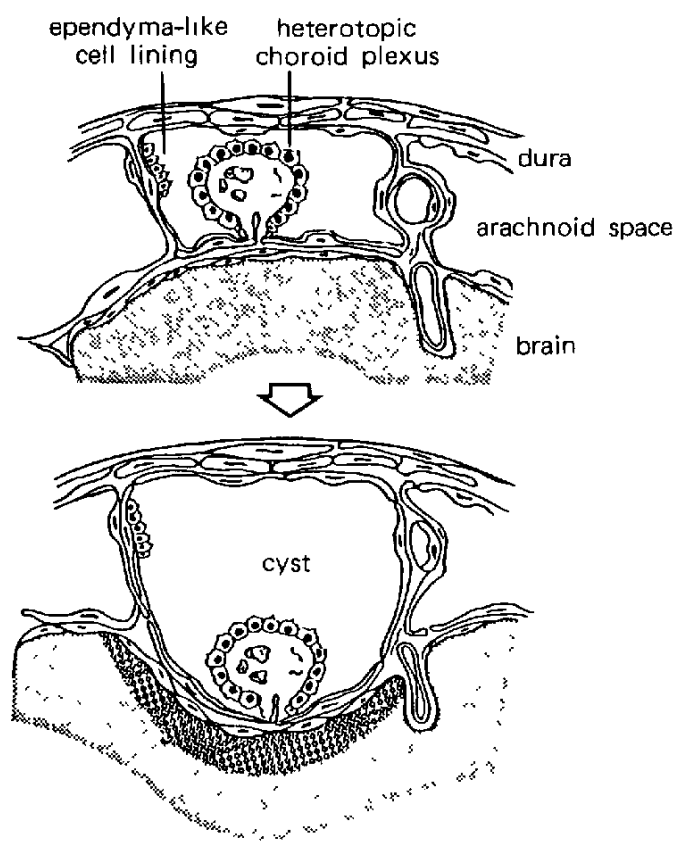

Fig. 5 Presumed pathogenesis of arachno1d cysts containing chorold plexus or ependyma-like cell lining Heterotopic choroid plexus and/or ependyma may secrete cerebrospinal flusd and split the arachnoid membrane, forming a growing cyst.

ち半数以上の症例においてこれらの組織中に ependymal cell を含んでいたと述べている，さらに，1964年，Popoff らの゙ は spina bifida を有した新生児の剖検例で leptomeningeal connective tissue $の$ 中 $K$ ependymal cell lining $と と も$ に choroid plexusを見出している。このような heterotopic ependymal cell p choroid plexus があらかじめ存在し、こ れらによる檤液産生が豊胞腔を作り出す起因となる可能性 は十分に考克られるのではなかららか(Fig. 5)。をた，今 回我々の経験した malignant choroid plexus papilloma 1 例では脳室ドレナージを行った部位に䯣液内播種をきたし たと考兄られた tumor tissueより鹃液が産生され，クモ膜

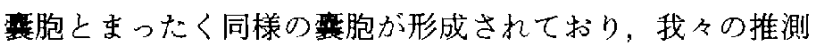
を裏付ける貴重な症例となるものと思われた。

\section{V ま と}

CT 導入以来，クモ膜襄胞の診断は容易之なり，積拯的 な外科的療法が行われている，過去10年間俄手名手術を 行い，2 年以上 follow-up した症例は48例であるが，その らち90〜100\%の赭胞の縮小が認められたものは12例(25\%) であり，30〜80\%の縮小をみたものは27例(56\%)，維小率 が0〜20\%であったものは 9 例(19\%)であった。こらした
手術結果の違いに関しては，クモ膜豪胞の発生括よび增大 因子など，さまざすな要因が考えられた，そこで，今回さ らに剖検の行われた11症例を加え，合計59症例の襄胞壁を 中心とした詳細な組織学的検討を行ったところ，光顕的に は典型的なクモ膜細胞より成る衰胞壁が全例に認められ た。ところが，縮小率の不良であった1例および剖検例の 1 例において霬胞壁内に choroid plexus 様の組織像が認め られ，電䫓的にもこれが確認された。旮こでこういった 構造物が果してクモ膜裹胞の成因と成りらるか否かを㛟討 し，文献的考察を加えた。

\section{文献}

1) Azzam NI, Timperley WR: Intracerebral cyst due to ectopic choroid plexus. J Neurosurg 55: 651-653, 1981

2) Bright R: Serous cysts in the arachnoid, in Paternoster-Row, Highley $\mathrm{S}$ (eds): Reports of Medtcal Cases Selected with a View of Illustrating the Symptoms and Cure of Diseases by Reference to Morbid Anatomy, vol II. Diseases of the Brain and Nervous System, part 1 London, Longman, 1831, pp 437-439, cited in 10)

3) Cooper IS, Kernohan JW: Heterotopic glal nest in subarachnoid space: Histopathological characteristics, mode of origin, and relation to meningeal gliomas. J Neuropathol Exp Neurol 10: $16^{-29}, 1951$

4) Handa H, Bucy PC. Benign cysts of the brain simulating brain tumor. $J$ Neurosurg 13: 489-499, 1956

5) Iglesias JR, Sanjuanbenito L, Martinez-Cubells J, Lousa M, Redondo C: Intracerebral arachnoid cyst containing choroid plexus. Case report. Acta Neurochur (Wien) 58: 229-234, 1981

6) Kahm EA, Basset RC, Schneider RC, Crosby EC: Correlative Neurosurgery, ed I Springfield, CC Thomas, 1955, p 206

7) Nakagawa $Y$, Artıgas J, Iglesias J, Cervos-Navarro J, Sampaolo $S$ : Intracranial cyst containing choroid plexus: Case report and review. $J$ Neurosurg (in press)

8) 岡本順二，松本圭蔵：被膜切除を行った頭蓋内くも膜蓑腫. CT 研究 4: 553-563，1982

9) Popoff N, Feigin I: Heterotopic central nervous tissue in subarachnoid space. Arch Path (Chtcago) 78: 533-539, 1964

10) Rengachary $S$, Watanabe I, Brackett CE: Pathogenesis of intracranial arachno1d cyst. Surg Neurol 9: 139-144, 1978

11) Robinson RG: The temporal lobe agenesis syndrome. Brain 87 . 87-106, 1964

12) Shaw CM, Alvord EC: Congenital arachnoid cyst and their differential diagnosıs, in Vinken PJ, Bruyn GW (eds): Handbook of Clinucal Neurology Amsterdam, North-Holland, 1977, pp 75-135

13）志村俊郎，平野朝雄，小野道夫，Liene JF，竹下岩男，中

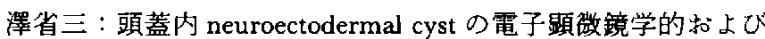

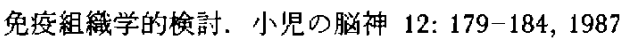

14) Starkman SP, Brown TC, Linell EA: Cerebral arachnold cysts. $J$ Neuropath Exp Neurol 17: 484-500, 1958

15）津田敏雄，上田伸，松本圭蔵：クモ膜葽腫の臨床病理学 
的検討. Neurol Med Chir (Tokyo) 21: 501-509, 1981

16) Williams B, Guthkelch AN: Why do central arachnoid pouches expand? J Neurol Neurosurg Psychiatry 37: 1085-1092, 1974
〔別刷請求先：干765 香川県善通寺市善通寺町 2,603 , 国立寮善 所香川小児病院眇神経外科，中川義信了 